\title{
Pemanfaatan daun jati (Tectona grandis) sebagai pakan ternak: Review
}

\section{Utilization of teak leaves (Tectona grandis) for animal feed component: A Review}

\author{
Ana Fitriyah', Chrisdina Aglistinova², Nadya Arsa Difa Rera ${ }^{3}$, Feby Agung \\ Pangestu $^{4}$, Habibilah ${ }^{5}$, Rizki Amalia Nurfitriani ${ }^{6^{*}}$, dan Sadarman ${ }^{7}$ \\ ${ }^{1}$ Program Studi Produksi Ternak, Jurusan Peternakan, Politeknik Negeri Jember, J. \\ Mastrip 164, Jember, 68121 \\ 2Program Studi Peternakan, Fakultas Pertanian dan Peternakan, UIN Sultan Syarif \\ Kasim Riau, Pekanbaru, Riau 28293 \\ *Email Koresponden: ranurfitriani@polije.ac.id
}

\begin{abstract}
Abstrak. Artikel ini bertujuan untuk mengetahui pemanfaatan daun jati (Tectona grandis) sebagai pakan ternak. Pakan memiliki peranan penting bagi ternak yakni untuk pertumbuhan dan produksi ternak. Indonesia memiliki banyak potensi alam yang dapat dijadikan sebagai pakan. Daun jati merupakan bagian dari pohon jati yang memiliki kandungan nutrient cukup baik dan berpotensi sebagai pakan ternak. Daun jati dapat mengantikan limbah pertanian dan hijauan terutama saat musim kemarau serta sebagai feed additive. Akan tetapi, pemberian daun jati tidak bisa diberikan secara langsung karena memiliki zat anti nutrisi tanin, tidak semua ternak dapat tahan terhadap zat anti nutrisi sehingga pemberian daun jati perlu pengolahan terlebih dahulu. Pengolahan daun jati selama ini dapat dilakukan melalui tiga acara yaitu dengan metode ekstraksi, penepungan, dan fermentasi. Hasil dari ketiga metode tersebut berbeda-beda sesuai tujuan pengolahannya. Penggunaan daun jati baik difermentasi, dimanfaatkan sebagai ekstrak dan tepung berpengaruh nyata terhadap produktivitas tenak. Hasil yang diperoleh yakni tepung daun jati pada level 1,2\% efektif untuk menggantikan antibiotik sintetis. Fermentasi daun jati dengan dosis $10 \%$ efisien mengunakan bakteri Actinobacillus sp. dapat menurunkan kandungan serat kasar dan meningkatkan kandungan protein kasar. Suplementasi fitobiotik ekstrak daun jati dengan pemberian 1,6\% mampu meningkatkan profil darah, khususnya trombosit, ayam petelur. Saran yang dapat diberikan untuk keberlanjutan pemanfaatan daun jati yaitu perlu dilakukan penelitian lebih lanjut untuk pemanfaatan daun jati pada ternak ruminansia.
\end{abstract}

Kata kunci: daun jati, ekstraksi, fermentasi, pakan, ternak

Abstract. This article aims to determine the use of teak (Tectona grandis) leaves as animal feed. The feed has an important role for livestock, namely for the growth and production of livestock. Indonesia has a lot of natural potentials that can be used as feed. Teak leaves are part of the teak tree which has a good nutrient content and has the potential to be used as animal feed. Teak leaves can replace agriculturally and forage waste, especially during the dry season, as a feed additive. However, giving teak leaves cannot be given directly because they have anti-nutritive tannins, not all livestock can be resistant to anti-nutrients, so giving teak leaves needs to be processed first. So far, teak leaf processing can be carried out in three ways, namely by extraction, flouring, and fermentation methods. The results of the three methods vary according to the purpose of processing. The use of teak leaves, whether fermented, used as extracts and flour, significantly affects livestock productivity. The 
Fitriyah et al.

ANIMPRO: Conference of Applied Animal Science Proceeding Series

results obtained are teak leaf flour at a level of $1.2 \%$ effective to replace synthetic antibiotics. Teak leaf fermentation with a dose of $10 \%$ efficient using Actinobacillus sp. can reduce crude fiber content and increase crude protein content. Phytobiotic supplementation of teak leaf extract by giving $1.6 \%$ was able to improve the blood profile, especially platelets, laying hens. Suggestions that can be given for the sustainability of the use of teak leaves are that further research is needed for the utilization of teak leaves in ruminants.

Keywords: teak leaves, extraction, fermentation, feed, livestock

\section{PENDAHULUAN}

Pakan memiliki peranan penting bagi ternak yakni untuk pertumbuhan, mempertahankan hidup, Ternak dengan pemberian pakan yang baik akan menghasilkan produk (susu, daging, dil), tenaga yang dapat dimanfaatkan manusia (Supartini \& Fitasari, 2011). pakan yang diberikan pada ternak sebaiknya dapat memenuhi kebutuhan dan dalam jumlah cukup. Di Indonesia salah satu kendala peternakan sapi potong yakni dalam meningkatkan PBB (yanuartono et al., 2017). Salah satu faktor yang mempengaruhi PBB adalah ketersediaan pakan. Kekurangan bahan pakan ternak dalam jumlah dan kualitas yang kurang sering terjadi di Indonesia, khususnya pada musim kemarau. Melimpahnya daun jati kering di musim kemarau dapat dimanfaatkan sebagai alternatif pakan sapi potong. Daun jati (Tectona grandis) bisa untuk pakan ternak karena pada kandungan kimia daun jati tidak terdapat bahan-bahan yang membahayakan. Bahkan daun jati juga masih mengandung protein kasar yang masih lumayan bagus untuk ternak meskipun tidak tergolong tinggi. Daun jati yang rontok dari pohon jati pada musim kemarau tersedia dalam jumlah cukup banyak serta mudah diperoleh sehingga memberikan peluang bagi peternak untuk memanfaatkan daun jati sebagai alternatif pakan ternak ruminansia (yanuartono et al., 2017).

Kendala pemanfaatan daun jati sebagai pakan ternak ruminansia adalah kandungan serat kasarnya cukup tinggi, yakni sebesar $22,9 \%$ dan kadar proteinnya rendah yaitu $4,9 \%$ (Lamid et al., 2013). Kadar protein yang rendah menyebabkan terhambatnya aktivitas mikroba rumen serta tidak dapat memenuhi kebutuhan pokok sapi serta kandungan serat kasar yang cukup tinggi menyebabkan tingkat kecernaan rendah. Peningkatan nilai gizi daun jati dan nilai kecernaan dapat ditingkatkan dengan beberapa cara salah satunya yakni dengan fermentasi yang memanfaatkan jasa mikroorganisme seperti jamur dan bakteri (Lamid et al., 2013). Fermentasi memiliki keuntungan antara lain tidak menimbulkan polusi, mampu meningkatkan nilai nutrisi bahan pakan, menghilangkan zat antinutrisi yang terkandung dalam bahan mentah, dan membutuhkan waktu relatif pendek. Selain itu pemanfaatan daun jati bisa dilakukan dengan membuat tepung daun jati sebagai bahan pakan ternak dan ekstrak daun jati dapat dimanfaatkan sebagai feed aditif pakan unggas. Pada review ini akan dibahas mengenai pengolahan dan pemanfaatan daun jati sebagai pakan ternak.

\section{Daun Jati}

Daun jati (Tectona grandis L.) memiliki potensi dimanfaatkan sebagai aditif pakan pengganti antibiotik. Daun jati mengandung komponen bioaktif berupa flavonoid, steroid, dan antosianin yang dapat berfungsi sebagai agen antibakteri dan mengandung aktivitas antioksidan yang mendukung produktivitas, sehingga dapat meningkatkan profitabilitas usaha ternak unggas (Dechayont et al., 2021). Selain itu, daun jati juga mengandung tannin yang merupakan zat anti nutrisi (Edi et al., 2018). Zat anti nutrisi tersebut dapat dihilangkan atau dikurangi dengan cara fermentasi, pengeringan, dan ekstraksi (Jayanegara et al., 2019). Hasil analisis proksimat, Nutrisi yang terkandung pada daun jati yaitu BK $80 \%$, PK $10 \%$, SK $20 \%$, LK $4.5 \%$, dan TDN $45 \%$ (Hariyono, 2021). Tingkat kecernaan yang sedang serta kandungan protein kasar yang cukup bagus pada daun jati menunjukan bahwa daun jati masih layak diberikan pada ternak terutama ternak sapi sehingga dapat mengatasi permasalahan minimnya hujauan dimusim kemarau. Namun, kandungan serat kasar yang cukup tinggi menyebabkan kecernaan pakan rendah sehingga diperlukan pengolahan terlebih dahulu. Selain itu, daun jati muda mengandung pigmen 
Fitriyah et al.

ANIMPRO: Conference of Applied Animal Science Proceeding Series

antosianin, pheophiptin, $\beta$-karoten, pelargonidin 3- glukosida, pelargonidin 3,7-diglukosida, klorofil dan dua pigmen lain yang belum diidentifikasi (Edi et al., 2018). Ekstrak daun jati mengandung bioaktif (flavonoid, antioksidan dan antosianin). Bioaktif tersebut mempunyai aktivitas antibakteri, antioksidan, dan antijamur yang dapat meningkatkan fungsi saluran pencernaan sehingga meningkatkan kecernaan pakan. Bioaktif dari fitobiotik dapat meningkatkan palatibilitas dan kualitas pakan (sensory aspects). Flavonoid merupakan metabolit sekunder dari tanaman yang memiki sifat antibakteri, antijamur, dan anti-inflamasi sehingga, dapat menyeimbangkan mikroflora usus, mengoptimalkan saluran pencernaan, dan meningkatkan proses pencernaan pakan (Edi et al., 2018).

\section{Pemanfaatan Daun Jati sebagai Pakan Ternak}

Pemanfaatan daun jati sebagai pakan ternak memiliki potensi yang cukup baik. Pemberian daun jati dapat dilakukan dengan berbagai cara pengolahan. Cara pengolahan daun jati yang sudah pernah dibuat yaitu ekstraksi, penepungan, dan fermentasi.

\section{Ekstraksi Daun Jati}

Ekstraksi merupakan suatu proses yang dilakukan dengan pemisahan bahan menggunakan pelarut sesuai bahan yang ingin dipisahkan (Mukhtarini, 2011). Macam-macam metode ekstraksi yang dapat digunakan adalah maserasi, Ultrasound-Assisted Solvent Extraction, Perkolasi, Soxhlet, dan Reflux atau destilasi uap. Senyawa fitokimia yang sudah diekstraksi dari daun jati yaitu Acetovanillone, E-isofuraldehyde, Evofolin, Syringaresinol, medioresinol, balaphonin, lariciresinol, zheberesinol, I-hydroxypinoresinol, dan dua kandungan baru yaitu Tectonoelin A dan Tectonoelin B (Rodney et al, 2012). (Januarti et al., 2017) melaukan ekstraksi daun jati dengan metode Ultrasound-Assisted Solvent Extraction dengan memberi perbedaan rasio sebagai perlakuan. Kualitas ektraksi daun jati berbeda sesuai dengan perbedaan rasio tepung daun jati dan pelarut (etanol $70 \%$ ) yang ditambahkan. Rasio daun jati dan etanol $70 \%$ sebesar $1: 5$ menunjukkan kadar air sebesar 3,81\%, rasio $1: 10$ menghasilkan kadar air 3,61\%, dan rasio 1:15 menghasilkan kadar air sebanyak 6,84\%. Menurut Depkes (2008) kadar air hasil ekstrakasi yang baik yaitu kurang dari 10\%. Ekstraksi daun jati menggunakan metode ultrasonik yang memiliki kadar flavonoid total tertinggi dengan rasio bahan : pelarut 1:5 dan lama waktu ekstraksi 30 menit (Januarti et al., 2017). (Nur et al., 2019) melakukan ekstraksi daun jati untuk menentukan adanya korelasi antara kadar total flavonoid dan fenolik dari fraksi daun jati terhadap aktivitas antioksidan. Ekstraksi yang dilakukan menggunakan metode maserasi dengan perlakuan terdiri dari tiga pelarut yaitu etanol $70 \%$, etil asetat dan n-Heksan. Hasil peneltian (Nur et al., 2019) menunjukkan bahwa kadar flavonoid tertinggi terdapat pada pelarut etil asetat sebesar $3,88 \%$, dan kandungan total fenolik terbesar yaitu dengan oenambahan pelarut etil asetat sebesar $11,59 \%$. Korelasi antara kadar total flavonoid dan fenolik dari ekstrak dan fraksi terhadap aktivitas dalam meredam radikal DPPH dan ABTS diperoleh korelasi sedang sedangkan hubungan terhadap daya reduksi besi pada pengujian FRAP diperoleh korelasi yang tinggi.

\section{Penepungan Daun Jati}

Teknologi penepungan adalah salah satu metode pengolahan yang menghasilkan produk setengah jadi. Penepungan bertujuan untuk memudahkan pencampuran sebagai bahan pangan. Keunggulan dari bahan yang diolah menjadi tepung yaitu lebih mudah dalam penyimpanan, umur simpan lebih lama, penggunaanya lebih luas, lebih mudah difortifikasi, dan lebih mudah bercampur dengan bahan lain (komposit) (Marta, 2011). Pembuatan tepung daun jati oleh (Edi et al., 2018) yaitu dengan proses pelayuan terlebih dahulu selama 24 jam, kemudian dikeringkan dalam oven pada suhu $45^{\circ} \mathrm{C}$ sealam 36 jam dan digiling menjadi tepung hingga ukuran 60 mesh.

\section{Fermentasi Daun Jati}

Fermentasi merupakan suatu proses yang memanfaatkan mikroba dengan tujuan merubah substrat menjadi produk yang diinginkan (Dias et al., 2018) Metode fermentasi dibidang Peternakan umum digunakan dalam pengolahan pakan dan pengolahan hasil ternak. Tujuan dari 
Fitriyah et al.

ANIMPRO: Conference of Applied Animal Science Proceeding Series

adanya metode fermentasi ini adalah untuk menjaga kualitas bahan, meningkatkan nilai nutrisi bahan dalam ini pakan, dan menghilangkan zat anti nuttrisi yang terdapat dalam bahan mentah (Yunianta \& Hartatik, 2015) melakukan fermentasi daun jati dengan penambahan starter yang terdiri dari 4 perlakuan yaitu T0: control, T1: SOC, T2: EM4, dan T3: Trichoderma sp. Hasil penelitian Yunianta dan Hartatik (2015) menunjukkan Trichoderma sp. meningkatkan kualitas silase daun jati yang dilihat dari kualitas fisik (warna, bau, tekstur dan jamur) secara signifikan $(P<0,05)$ dengan masa fermentasi selama 14 hari, sehingga hal ini berarti Trichoderma sp. merupakan starter yang dapat ditambahkan untuk fermentasi daun jati.

Tabel 1. Penelitian yang terkait dengan pemanfaatan daun jati sebagai pakan ternak.

\begin{tabular}{cll}
\hline Peneliti & \multicolumn{1}{c}{ Perlakuan } & \multicolumn{1}{c}{ Hasil Penelitian } \\
\hline 1 & 2 & \multicolumn{1}{c}{3} \\
\hline Edi (2018) & Pemberian tepung daun jati dengan & Penggunaan tepung daun jati \\
& $\begin{array}{l}\text { level pemberian 0,4\%; 0,8\%; } 1,2 \% ; \\
\text { dan 1,6\% dari total ransum yang } \\
\text { diberikan. }\end{array}$ & $\begin{array}{l}\text { pada level 1,2\% efektif untuk } \\
\text { menggantikan antibiotik sintetis }\end{array}$
\end{tabular}

Lamid et al. (2013) $\quad$ P0 $=500 \mathrm{~g}$ daun jati + tetes $2 \%$ (kontrol), $\mathrm{P} 1=500$ gr daun jati + tetes $2 \%+5 \%$ Actinobacillus sp.; $\mathrm{P} 2=500$ gr daun jati+ tetes $2 \%+$ $10 \%$ Actinobacillus sp.; P3 $=500 \mathrm{~g}$ daun jati + tetes $2 \%+15 \%$ Actinobacillus sp.

Inokulasi Actinobacillus sp. pada fermentasi daun jati dapat menurunkan kandungan serat kasar, meningkatkan kandungan protein kasar. Dosis efisien untuk fermentasi daun jati menggunakan bakteri Actinobacillus sp. adalah $10 \%$. Pemberian tepung daun

Budiarto et al. $\quad$ P0: $0 \mathrm{~g}$ tepung daun jati (kontrol), (2016) $\mathrm{P} 1: 5 \mathrm{~g}$ tepung daun jati, P2: $10 \mathrm{~g}$ tepung daun jati, P3: $15 \mathrm{~g}$ tepung daun jati, dan P4: $20 \mathrm{~g}$ tepung daun jati dalam $1.000 \mathrm{~g}$ pakan komplit. jati belanda (Guazuma ulmifolia Lamk.) pada dosis $5 \mathrm{~g}, 10 \mathrm{~g}, 15 \mathrm{~g}$ dan $20 \mathrm{~g}$ dalam $1 \mathrm{~kg}$ pakan komplit mampu menurunkan kadar trigliserida darah dan lemak abdominal ayam broiler $((\mathrm{P}<0.05)$ dibanding dengan kontrol.

Edi et al. (2020) Pakan basal tanpa aditif pakan (kontrol), pakan basal + 0,05\% antibiotik virginiamycin $(\mathrm{AB})$ dan pakan basal + Fitobiotik Ekstrak Daun Jati pada level 0,4\%, 0,8\%, $1,2 \%$ dan $1,6 \%$.

Achmadi et al. $\mathrm{P} 0$ : pakan kontrol; $\mathrm{P} 1$ : (2021) penambahan ekstrak daun jati 0,8\%; P2: penambahan ekstrak daun jati $1,2 \%$; dan P3: penambahan ekstrak daun jati $1,6 \%$.

Suplementasi fitobiotik ekstrak daun jati dengan pemberian $1,6 \%$ mampu meningkatkan profil darah, khususnya trombosit, ayam petelur.

Penambahan ekstrak daun jati pada pakan memberikan pengaruh yang tidak nyata $(P<0,5)$ terhadap konsumsi, produksi hen day (HDP), konversi pakan, massa telur, dan pendapatan di atas biaya pakan (IOFC)

\section{Pemanfaatan Daun Jati sebagai Pakan Ternak}

Menurut penelitian yang dilakukan oleh (Lamid et al., 2013), Pemanfaatan daun jati sebagai pakan ternak dapat dilakukan dengan cara difermentasi menggunakan bakteri selulolitik (Actinobacillus sp.) sebagai inoculum yang ditumbuhkan dalam media cair dapat menurunkan kandungan serat kasar, meningkatkan kandungan protein kasar, dan berpotensi sebagai 
Fitriyah et al.

ANIMPRO: Conference of Applied Animal Science Proceeding Series

alternatif pakan ternak ternak ruminansia terutama di musim kemarau. Dosis efisien untuk fermentasi daun jati menggunakan bakteri Actinobacillus sp. adalah $10 \%$ yang mampu menurunkan kandungan serat kasar dengan jumlah dosis yang relatif lebih rendah sehingga dapat menekan biaya penggunaan bakteri selulolitik. Rendahnya kadar serat kasar menunjukkan terjadi perkembangbiakan yang pesat dari mikroorganisme pendegradasi selulosa karena kondisi yang sesuai.

Rendahnya kandungan bahan organik karena karbohidrat oleh mikroba didegradasi sebagai sumber karbon untuk perkembangan, pertumbuhan, dan aktivitas dalam menguraikan komponen serat kasar (selulosa dan hemiselulosa). Serat kasar rendah karena Actinobacillus sp. mampu mendegradasi selulosa dan hemiselulosa secara optimal disebabkan enzim selulase yang dihasilkan bekerja pada waktu pemeraman selama tujuh hari telah mampu melonggarkan ikatan â-1,4- glikosidik pada komponen selulosa sehingga terjadi pemecahan komponen struktur selulosa menjadi bentuk oligosakarida yang menyebabkan terjadinya penurunan kandungan serat kasar. Protein kasar tinggi karena peningkatan aktivitas Actinobacillus sp. dalam mengikat nitrogen sebagai bahan dasar untuk sintesis protein. Sementara itu, dalam penelitian yang dilakukan oleh Haryono (2021), daun jati dan batang pisang dapat dimanfaatkan sebagai pakan ternak dan kompos melalui fermentasi. Alternatif pakan tersebut dapat mengatasi permasalahan kurangnya hijauan di musim kemarau, dimanfaatkan sebagai pupuk organik yang dapat meningkatkan pertumbuhan dan hasil tanaman, dan meningkatkan kesuburan tanah.

Menurut penelitian yang dilakukan oleh (Edi et al., 2018), Tepung daun jati dapat digunakan sebagai aditif pakan untuk meningkatkan profitabilitas ayam petelur dan penggunaan tepung daun jati pada level $1,2 \%$ efektif untuk menggantikan antibiotik sintetis dan meningkatkan total massa telur karena berkaitan erat dengan kandungan fitokimia yang dimiliki daun jati. Tepung daun jati mengandung flavonoid sebesar $0,17 \%$ yang merupakan antibakteri dalam saluran pencernaan, dan aktivitas antioksidan sebesar 56,22\% dapat meningkatkan tinggi vili yang mendukung proses pencernaan dan penyerapan nutrien sehingga meningkatkan produktivitas. Peningkatan total massa telur diikuti dengan meningkatnya pendapatan penjualan telur yang berakibat terhadap peningkatan keuntungan dan nilai $\mathrm{R} / \mathrm{C}$ ratio ayam petelur, namun tidak berpengaruh terhadap palatabilitas dan total konsumsi ransum karena penambahan tepung daun jati pada level rendah sehingga perlakuan tidak memberikan banyak perubahan terhadap kandungan nutrien pada ransum.

Meningkatnya konsumsi pakan sejalan dengan kandungan bioaktif (flavonoid) yang mengandung antibakteri yang dapat menyeimbangkan mikroflora usus dan mengoptimalkan saluran pencernaan sehingga proses pencernaan pakan meningkat. Peningkatan HDP (hen day production) karena ekstrak daun jati mengandung bioaktif yang dapat menurunkan bakteri patogen. Mikroba dalam saluran pencernaan dapat merangsang sel globet pada dinding halus untuk memproduksi dan meningkatkan mucus sehingga dapat meningkatkan penyerapan nutrisi dan memaksimalkan HDP. Peningkatan eggmas sejalan dengan peningkatan HDP dan berat telur, karena eggmass merupakan hasil perkalian dari HDP dan berat telur sehingga nilainya akan berbanding lurus. Nilai FCR mengalami peningkatkan seiring dengan level penambahan ekstrak daun jati. Penambahan ekstrak daun jati menyebabkan peningkatan kecernaan pakan sehingga angka konversi ransum lebih rendah dan hasil semakin menguntungkan.

\section{KESIMPULAN}

Penggunaan daun jati pada ternak berpengaruh nyata terhadap produktivitas ternak. Pengolahan daun jati dapat dilakukan dengan cara fermentasi, penepungan, dan ekstraksi. Cara tersebut dapat menghilangkan dan meminimalisir zat anti nutrisi baik difermentasi. Daun jati dapat dimanfaatkan sebagai pakan ternak penganti limbah pertanian dan hijauan saat musim kemarau serta kandungan bioaktif berupa flavonoid, steroid, dan antosianin dapat dimanfaatkan sebagai feed additive. Saran yang dapat diberikan untuk keberlanjutan pemanfaatan daun jati yaitu perlu dilakukan penelitian lebih lanjut untuk pemanfaatan daun jati pada ternak ruminansia. 
Fitriyah et al.

ANIMPRO: Conference of Applied Animal Science Proceeding Series

\section{DAFTAR PUSTAKA}

Achmadi, P. C., Sudjarwo, E., \& Djunaidi, I. H. (2021). The Effect of Teak Leaf Extract Addition (Tectona grandis Linn . F) to Feed on Laying Quails Production Performance. 31-34. https://doi.org/10.9790/1813-1004023134

Budiarto, M. A., Yuniwarti, E. Y. W., \& -, I. (2016). Pengaruh Pemberian Tepung Daun Jati Belanda (Guazuma ulmifolia L.) dalam Pakan terhadap Kadar Trigliserida Darah dan Lemak Abdominal Ayam Broiler. Buletin Anatomi Dan Fisiologi, 1(1), 43. https://doi.org/10.14710/baf.1.1.2016.43-47

Dechayont, B., Phuaklee, P., Chunthorng-Orn, J., Juckmeta, T., Prajuabjinda, O., \& Jiraratsatit, K. (2021). Antibacterial, anti-inflammatory and antioxidant activities of Mahanintangtong and its constituent herbs, a formula used in Thai traditional medicine for treating pharyngitis. BMC Complementary Medicine and Therapies, 21(1), 1-12. https://doi.org/10.1186/s12906-021-03274-6

Dias, A. L. G., Freitas, J. A., Micai, B., Azevedo, R. A., Greco, L. F., \& Santos, J. E. P. (2018). Effect of supplemental yeast culture and dietary starch content on rumen fermentation and digestion in dairy cows. Journal of Dairy Science, 101(1), 201-221. https://doi.org/10.3168/jds.2017-13241

Edi, D. N., Natsir, M., \& Djunaidi, I. (2018). Pengaruh penambahan ekstrak daun jati (tectona grandis linn. F) dalam pakan terhadap performa ayam petelur. Jurnal Nutrisi Ternak Tropis, 1(1), 33-44. https://doi.org/10.21776/ub.jnt.2018.001.01.5

Edi, D. N., Natsir, M. H., \& Djunaidi, I. H. (2020). Profil Darah Ayam Petelur yang Diberi Pakan dengan Penambahan Fitobiotik Ekstrak Daun Jati (Tectona grandis Linn. f). Jurnal Peternakan, $17(2), 96$. https://doi.org/10.24014/jupet.v17i2.10130

Hariyono, H. (2021). Pemanfaatan Batang Pisang Dan Daun Jati Sebagai Pakan Ternak Dan Kompos Melalui Fermentasi. Seminar Nasional Hasil Pengabdian Kepada Masyarakat, 1(2), 128-135.

Januarti, I. B., Santoso, A., \& Razak, A. S. (2017). Flavonoid Extraction of Teak Leaf (Tectona grandis L.) with Ultrasonic Method (Study Of Material:Solvent Ratio and Extraction Time) Program Studi Farmasi Fakultas Kedokteran Universitas Islam Sultan Agung Jl. Kaligawe KM 4 Semarang 50012 Telp.(+6224) 6583. Media Farmasi Indonesia, 12(2), 1263-1270.

Jayanegara, A., Ridla, M., Laconi, E. B., dan N. (2019). Anti Antinutrisi pada Pakan (1st ed.). PT Penerbit IPB Press.

Lamid, M., Foetus, A., Julita, E., Made, N., Widjaya, R., Peternakan, D., Kedokteran, D., Veteriner, D., Hewan, F. K., Airlangga, U., \& Unair, K. C. (2013). Inokulasi Bakteri Selulolitik Actinobacillus sp . Asal Rumen pada Daun Jati Menurunkan Serat Kasar dan Meningkatkan Protein Kasar. 14(3), 279-284.

Mukhtarini. (2011). "Ekstraksi, pemisahan senyawa, dan identifikasi senyawa aktif." Jurnal of Pharmacy, V, 361.

Nur, S., Sami, F. J., Awaluddin, A., \& Afsari, M. I. A. (2019). Korelasi Antara Kadar Total Flavonoid dan Fenolik dari Ekstrak dan Fraksi Daun Jati Putih (Gmelina Arborea Roxb.) Terhadap Aktivitas Antioksidan. Jurnal Farmasi Galenika (Galenika Journal of Pharmacy) (e-Journal), 5(1), 33-42. https://doi.org/10.22487/j24428744.2019.v5.i1.12034

Supartini, N., \& Fitasari, E. (2011). Penggunaan Bekatul Fermentasi "Aspergillus Niger" Dalam Pakan Terhadap Karakteristik Organ Dalam Ayam Pedaging. Buana Sains, 11(2), 127-136.

yanuartono, yanuartono, Purnamaningsih, H., Indarjulianto, S., \& Nururrozi, A. (2017). Potensi jerami sebagai pakan ternak ruminansia. Jurnal Ilmu-Ilmu Peternakan, 27(1), 40-62. https://doi.org/10.21776/ub.jiip.2017.027.01.05

Yunianta, \& Hartatik. (2015). The Use of Trichoderma sp. as a Starter of Fermentation Dry Teak Leaves (Tectona grandis) as Animal Feed. The 6th International Seminar on Tropical Animal Production Integrated Approach in Developing Sustainable Tropical Animal Production. October 20-22, 2015, Yogyakarta, Indonesia, 291-295. 